\title{
Variation among Populations of the Troglobitic Amphipod Crustacean Crangonyx antennatus Packard (Crangonyctidae) \\ Living in Different Habitats, III: Population Dynamics and Stability
}

\author{
Gary W. Dickson* \\ and \\ John R. Holsinger**
}

\begin{abstract}
SUMMARY
Populations of the troglobitic amphipod Crangonyx antennatus from caves in Lee Co., Virginia (U.S.A.) were investigated on both a short and long term basis. The dynamics of populations living in two distinct aquatic cave habitats (mud-bottom pools and gravel-bottom streams) were compared seasonally for one year. Sex ratios indicated a larger number of females in both pool and stream habitats. The majority of males in both habitats were found to be sexually mature throughout the year investigated. Seasonal fluctuations in female maturity were observed in both habitats, with larger numbers collected in June and August. In addition, a larger number of ovigerous females were observed in the spring, indicating the possibility of a circannian reproductive cycle in both pools and streams. The structure of populations from the caves studied appears to reflect a controlled recruitment of females from immature to mature stages. In order to determine the stability of population structure, collection data from a pool and a stream habitat for a 10-year period were analyzed. Population structures were found to be relatively stable over long periods in both habitats, with immature females comprising the dominant population class.
\end{abstract}

\section{INTRODUCTION}

The population structure and dynamics of troglobitic species (i.e., obligatory cavernicoles) have been of interest because of the unique characteristics of the cave environment. These include the relative constancy of physical and chemical parameters and the lack of major food sources. In general, troglobitic species exhibit K-selected population characteristics (MacArthur and Wilson, 1967), including small population size, late maturity, low reproductive rates, large size at hatching, and increased longevity. K-selected properties have previously been reported in populations of aquatic troglobites, inclu-

* Health and Environmental Review Division, Office of Toxic Substances, Environmental Protection Agency - Washington, D.C. 20460, U.S.A. .

** Department of Biological Sciences, Old Dominion University - Norfolk, Virginia 23508 U.S.A. . 
ding fish (Heuts, 1951; Poulson, 1963), crayfish (Hobbs, 1973; Cooper, 1975; Cooper and Cooper, 1976, 1978; Franz, 1978), shrimp (Cooper, 1975; Cooper and Cooper, 1974), amphipods (Ginet, 1960; Holsinger and Holsinger, 1971), isopods (Magniez, 1975; Henry, 1976), and gastropods (Turner and Clench, 1974). An excellent review of earlier literature dealing with this subject is presented in Vandel (1965).

In the present study, population dynamics and stability were investigated in the troglobitic amphipod Crangonyx antennatus. This widespread species inhabits two distinct types of cave habitats (mud-bottom pools and gravel bottom streams) in the southern Appalachians of the eastern United States (Holsinger, 1969, 1972). Crangonyx antennatus has been found to exhibit both morphological and behavioral differences associated with these habitat types (Dickson, 1977a, 1977b). The presence of this species in two habitats offers a unique opportunity to study the dynamics and stability of a troglobitic species under different selective pressures.

The present investigation was conducted to: (1) determine the structure and dynamics of $C$. antennatus populations over a seasonal cycle, (2) compare population characteristics between stream and pool habitats, and (3) examine the stability of population structure over a relatively long period.

\section{METHODS AND MATERIALS}

Populations of $C$. antennatus were sampled seasonally from six caves in Lee Co., Virginia, during 1974 and 1975. Crangonyx antennatus populations are relatively large in this area, allowing selective sampling without disturbing population stability. Three of the populations sampled inhabited mudbottom pools (Roadside No. 1, Molly Wagle, and Sweet Potato caves) and three inhabited gravel-bottom streams (Spangler, Cope, and Gallohan No. 2 caves). In general, mud-bottom pool habitats contained greater quantities of available food, fewer predators, and smaller numbers of potential competitors than stream habitats. A complete ecological description of these aquatic habitats has been reported elsewhere (Dickson and Kirk, 1976; Dickson, 1977a).

Ten sample sites of $0.09 \mathrm{~m}^{2}$ were randomly selected in stream and pool areas of each cave during four seasonal sampling periods. All $C$. antennatus observed within the sampling sites, including any present in the top $5 \mathrm{~cm}$ of gravel in the stream habitats, were collected until 25 amphipods were obtained from each cave. Amphipods were preserved in $70 \%$ ethyl alcohol for later examination in the laboratory.

Each amphipod was examined to determine sex and life stage. Based on previous observations of this species, amphipods under $4.0 \mathrm{~mm}$ in body length (base of first antennate to base of telson) were considered juveniles. Males were distinguished by a pair of papillae on the sternum of the last thoracic segment, while females were distinguished by oostegites (brood plates) at the base of the second through fifth pereopods. Sexually mature males were recognized by the presence of calceoli (small, paddle-shaped structures) on 
the second antennae. Mature females possess long marginal setae on the margins of the oostegites. In addition, eggs contained within the brood pouch of females were counted and measured.

In conjunction with the population information gained from preserved material, live $C$. antennatus from both pool (Molly Wagle Cave) and stream (Spangler Cave) habitats were transported to the laboratory for study. Amphipods were kept in an environmental chamber under simulated cave conditions (i.e., $10^{\circ} \mathrm{C}$ in complete darkness). Pool-dwelling amphipods were placed in cultures containing mud sediments collected from their original habitat; stream-dwelling amphipods were reared with cave stream gravel and autumn shed leaves. Culture dishes were filled to a depth of $2 \mathrm{~cm}$ with spring water collected near the original habitats.

The long term stability of $C$. antennatus population structure was determined through examination of collection data acquired over a 10 -year period from 1965 to 1975. Crangonyx antennatus populations were sampled sporadically during this period in both a pool habitat cave (Molly Wagle Cave, 13 visits) and a stream habitat cave (Spangler Cave, six visits). The sex and life stage of amphipods from these collections were tabulated.

\section{RESULTS}

Male/Female Sex Ratios. In general, fewer males were found in C. antennatus populations in both habitats during the year studied (Fig. 1). Fluctuations were observed in this ratio seasonally, although no patterns appear present. No significant differences were observed in sex ratios between populations living in pool and stream habitats (Table 1).

To contrast cave and epigean amphipods of the genus Crangonyx, male/female sex ratios obtained by Sprules (1967) for the epigean amphipod C.richmondensis laurentianus were compared to sex ratios obtained for $C$. antennatus from pool and stream habitat caves. No differences were observed between the epigean and troglobitic Crangonyx species (Table 1).

A comparison of sex ratios was also made between $C$. antennatus and three troglobitic species of the genus Stygobromus (S. emarginatus, S. russelli and $S$. spinatus), which have previously been noted for their differential sex ratios favoring females (Culver and Holsinger, 1969; Holsinger, 1978). Significant differences $(\mathrm{P}<0.01)$ were found between sex ratios from both habitats and the Stygobromus values (Table 1).

Sexual Maturity. Crangonyx antennatus populations in both stream and pool habitats are characterized by a very high percentage of males which are sexually mature (Fig. 2). In contrast, the percentage of sexually mature females was relatively low. No significant differences $(P>0.05)$ were observed between lotic and lentic populations in the percentage of sexually mature males or females (Fig. 2, Table 2). In four of the six caves studied, increases in the number of mature females were observed in the June collection (Fig. 2).

Ovigerous Females and Juveniles. Both stream and pool habitats contained few ovigerous females, with greater numbers observed during February 
Galkhan 2

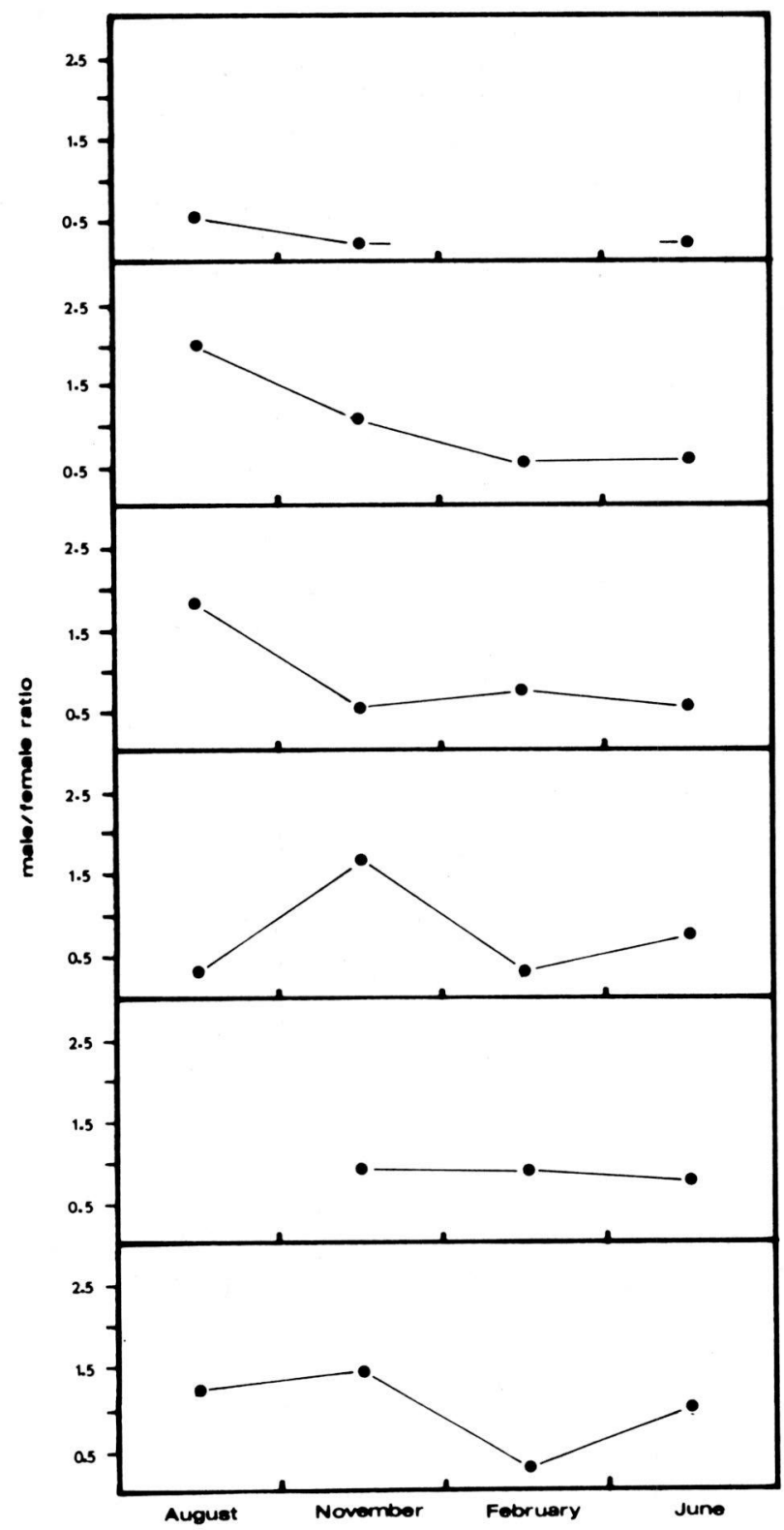

Spangler

Cope

Sweet Potato

Molly Wagle

Roadside I

Fig. 1. Male/female sex ratios of populations of $C$. antennatus sampled from each cave during seasonal collection periods. Due to adverse conditions, sampling could not be conducted in Molly Wagle Cave in August and Gallohan No. 2 Cave in February. 
Table 1. Comparison of Crangonyx antennatus sex ratios between habitats and with other epigean and troglobitic amphipod species. Crangonyx richmondensis sex ratios are from collections in a Canadian lake, whereas Stygobromus values are the average sex ratio of three troglobitic species: Stygobromus emarginatus, Stygobromus russelli, and Stygobromus spinatus. Significance is determined by the use of the MannWhitney U test.

\begin{tabular}{|c|c|c|c|c|}
\hline & $\begin{array}{l}\text { C. antennatus } \\
\text { Pool habitat }\end{array}$ & $\begin{array}{l}\text { C. antennatus } \\
\text { Stream habitat }\end{array}$ & C. richmondensis* & $\begin{array}{r}\text { Stygobromus** } \\
\text { species }\end{array}$ \\
\hline $\begin{array}{l}\text { C. antennatus } \\
\text { Pool habitat }\end{array}$ & 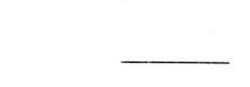 & $\begin{aligned} \text { N.S. }(P>0.05) \\
\mathrm{U}_{\mathrm{s}}=74.5\end{aligned}$ & $\begin{array}{r}\text { N.S. }(P>0.05) \\
U_{s}=36\end{array}$ & $\begin{array}{r}\text { Sig. }(P<0.01) \\
U_{\mathrm{s}}=118\end{array}$ \\
\hline $\begin{array}{l}\text { C. antennatus } \\
\text { Stream habitat }\end{array}$ & $\begin{array}{r}\text { N.S. }(P>0.05) \\
U_{s}=74.5\end{array}$ & - & $\begin{array}{r}\text { N.S. }(P>0.05) \\
U_{s}=27\end{array}$ & $\begin{array}{r}\text { Sig. }(P<0.01) \\
U_{\mathrm{s}}=118\end{array}$ \\
\hline
\end{tabular}

* Sprules, 1967.

** Culver and Holsinger, 1969; Holsinger, 1978. 


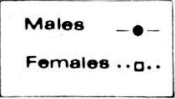

Gallohan 2

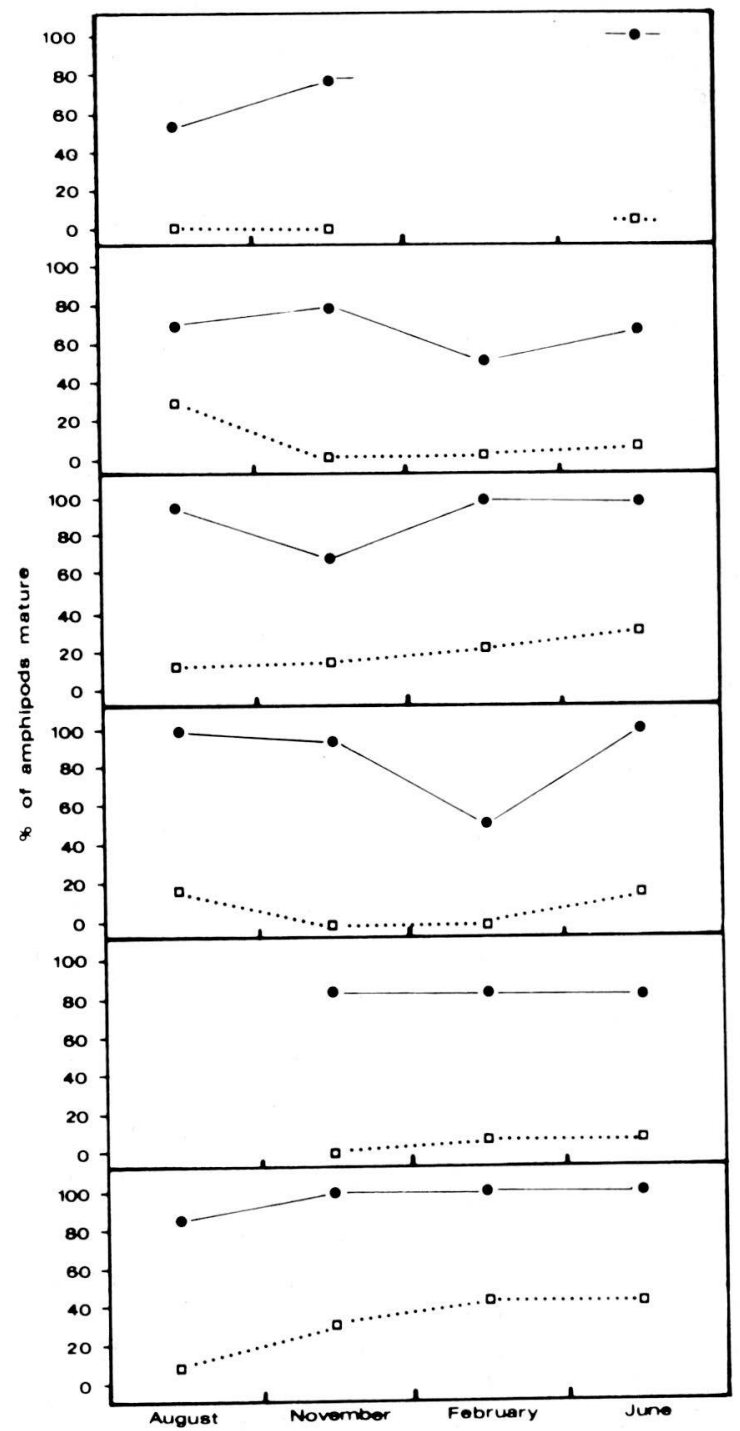

Fig. 2. The percentage of sexually mature individuals in populations of $C$. antennatus during seasonal collections. 
Table 2. Results of a two-way analysis of variance in sexual maturity of $C$. antennatus.

\begin{tabular}{|c|c|c|c|c|}
\hline & $\underset{\text { ratio }}{\mathrm{F}}$ & $\begin{array}{c}\text { Numerator } \\
\mathrm{df}\end{array}$ & $\underset{\mathrm{df}}{\text { Denominator }}$ & $\mathrm{P}$ \\
\hline $\begin{array}{l}\text { Percentage } \\
\text { males mature } \\
\text { between caves }\end{array}$ & 4.3 & 5 & 13 & $\begin{array}{l}\text { Sig. } \\
\mathrm{P}<0.05\end{array}$ \\
\hline $\begin{array}{l}\text { Percentage } \\
\text { males mature } \\
\text { between seasons }\end{array}$ & 2.3 & 3 & 13 & $\begin{array}{l}\text { N.S. } \\
P>0.05\end{array}$ \\
\hline $\begin{array}{l}\text { Percentage } \\
\text { males mature } \\
\text { between habitats * }\end{array}$ & 2.3 & 1 & 13 & $\begin{array}{l}\text { N.S. } \\
P>0.05\end{array}$ \\
\hline $\begin{array}{l}\text { Percentage } \\
\text { females mature } \\
\text { between caves }\end{array}$ & 9.0 & 5 & 13 & $\begin{array}{l}\text { Sig. } \\
\mathrm{P}<0.01\end{array}$ \\
\hline $\begin{array}{l}\text { Percentage } \\
\text { females mature } \\
\text { between seasons }\end{array}$ & 9.0 & 3 & 13 & $\begin{array}{l}\text { Sig. } \\
\mathrm{P}<0.01\end{array}$ \\
\hline $\begin{array}{l}\text { Percentage } \\
\text { females mature } \\
\text { between habitats } *\end{array}$ & 0.7 & 1 & 13 & $\begin{array}{l}\text { N.S. } \\
\mathrm{P}>0.05\end{array}$ \\
\hline
\end{tabular}

* A priori tests.

and June in five of the six populations (Fig. 3). No ovigerous females were collected in Gallahan No. 2 Cave, whereas Roadside No. 1 Cave contained relatively large numbers during the entire year.

The number of eggs within the brood pouch of ovigerous females was found to be significantly greater $(\mathrm{F}(1,19)=10.5 ; \mathrm{P}<0.01)$ in pool-dwelling populations $(\bar{X}=42)$ than in those living in stream habitats $(\bar{X}=28)$. A significant linear relationship is present between female body length and egg number $(\mathrm{n}=23 ; \mathrm{r}=0.519 ; \mathrm{P}<0.01)$. Mean egg size from both habitats was also calculated $(n=70 ; \bar{X}=0.49 \mathrm{~mm}$ diameter $)$.

The number of juveniles collected in stream populations was greater than from pool habitats (Fig. 3). No circannian pattern of juvenile presence in populations was apparent in seasonal sampling.

Longevity. Crangonyx antennatus survived readily under laboratory conditions with very little mortality. As reported in a previous study (Dickson, 1979), after two years of growth in the laboratory, juveniles from Molly Wagle Cave were found to be less than half the average adult size. During the preparation of this paper (August 1978), these amphipods were over four years old and still were not of adult body length. Additional adult individuals from both pool and stream populations have been kept in the laboratory for 
Juvenlles $\rightarrow-$
Ovigerous : 0 .
fomales

Gallohan 2

Spangler

Cope

Molly Wagle

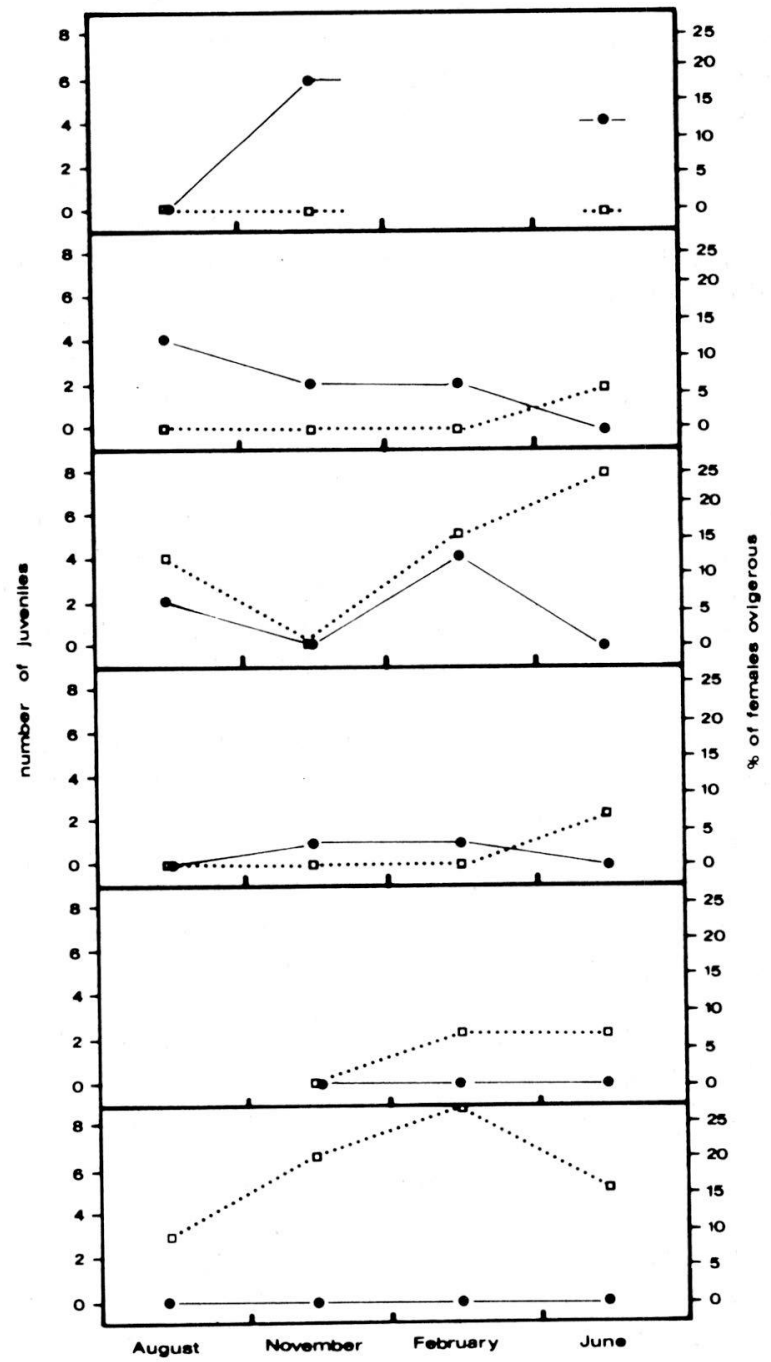

Fig. 3. The number of juveniles and the percentage of females which were ovigerous in $C$. antennatus populations from each cave during seasonal collection periods. 
a period of three to four years from the time of collection. It is inferred from laboratory cultures that $C$. antennatus may live as long as 8 to 10 years in nature.

Population Structure. The structure of $C$. antennatus populations was observed to be relatively constant in both pool and stream habitats over the year examined (Fig. 4). The largest population category was immature females, whereas mature females and juveniles made up the smallest groups. One exception to this generalized structure was the population inhabiting Roadside No. 1 Cave, which contained greater numbers of mature males and females.

Population Stability. The structure of $C$. antennatus populations was found to be stable over a 10-year period in both stream and pool habitats. Immature females were observed to be the largest population class; mature females and juveniles were the smallest classes (Fig. 5).

\section{DISCUSSION}

Results from the present study indicate that $C$. antennatus populations exhibit certain K-selected characteristics, including highly structured populations with selective maturity, low reproductive rates, and increased longevity. In addition to these generalized features, which are believed to be the products of selection, some population flexibility was observed due to individual habitat influence.

The sex ratios of $C$. antennatus were found to be more similar to an epigean congener, $C$. richmondensis, than to troglobitic species of Stygobromus (Table 1). This may indicate that the sex ratio of $C$. antennatus has not reached the level of cave specialization exhibited in the highly female dominated populations of troglobitic Stygobromus (Culver and Holsinger, 1969).

Populations of $C$. antennatus in stream and pool habitats were found to contain large numbers of sexually mature males $(\bar{X}=84 \%)$ throughout the year (Fig. 2). The high percentage of sexually mature males may increase the chance of breeding success by allowing mature males to be available in the population when conditions are periodically favorable for female maturation. In contrast, the number of mature females was relatively low $(\bar{X}=$ $13 \%$ ), with an increase observed in both habitats during spring and summer. This increase probably represents a response to more favorable food conditions.

In populations of all but one cave (Gallohan No. 2), seasonal fluctuations were observed in the number of ovigerous females (Fig. 3). The highest percentage of ovigerous females was seen in June, with initial increases in February. This seasonal peak may indicate a circannian reproductive pattern which follows increasing food availability and more optimal hydrological conditions. Ovigerous females were collected during other seasons only in the relatively food-rich habitats of Roadside No. 1, Molly Wagle, and Cope caves. This suggests that available food is one of the major factors controlling 


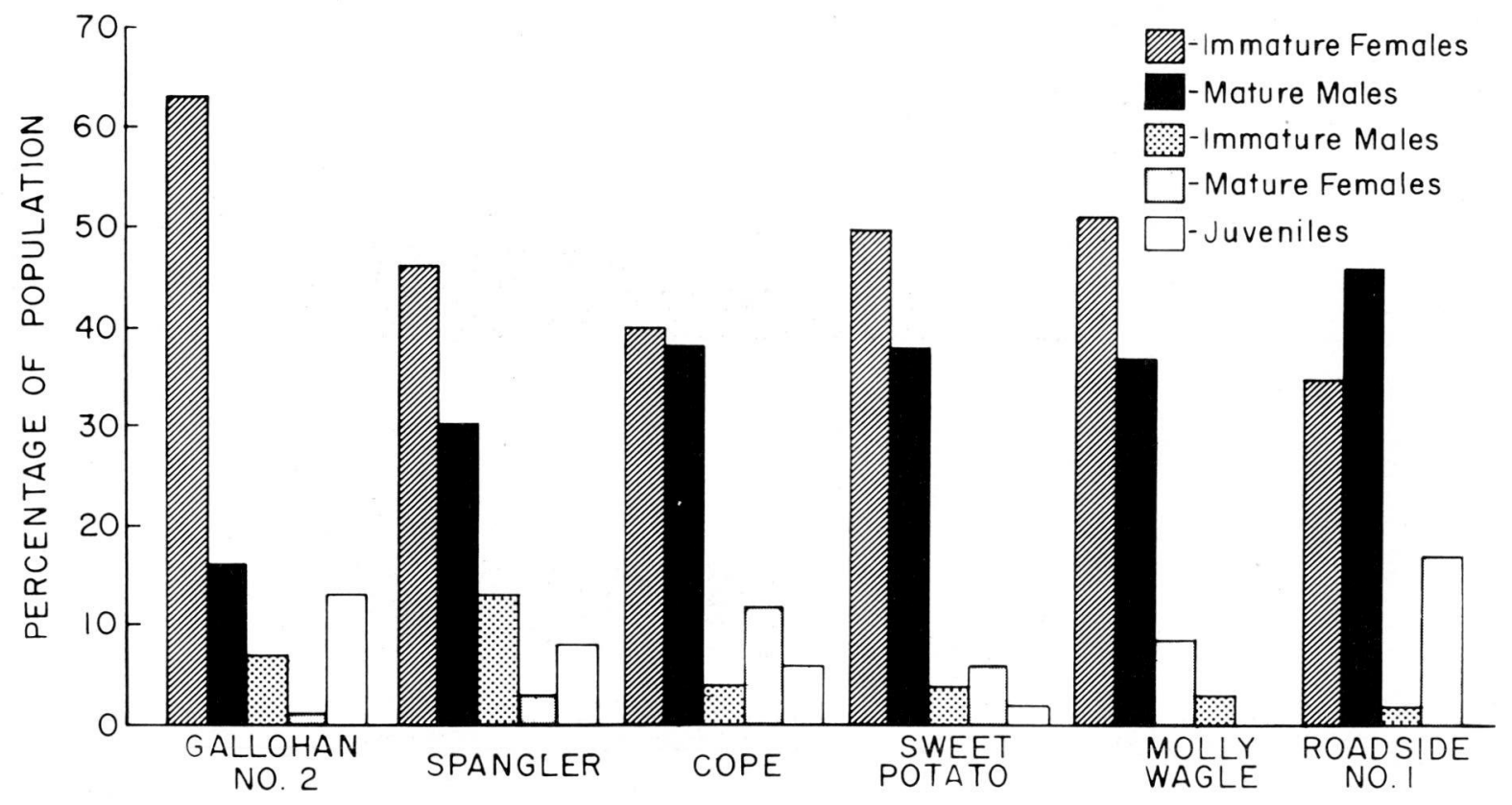

Fig. 4. Population structure of C. antennatus from the six investigated caves based on the total of four seasonal collections. 


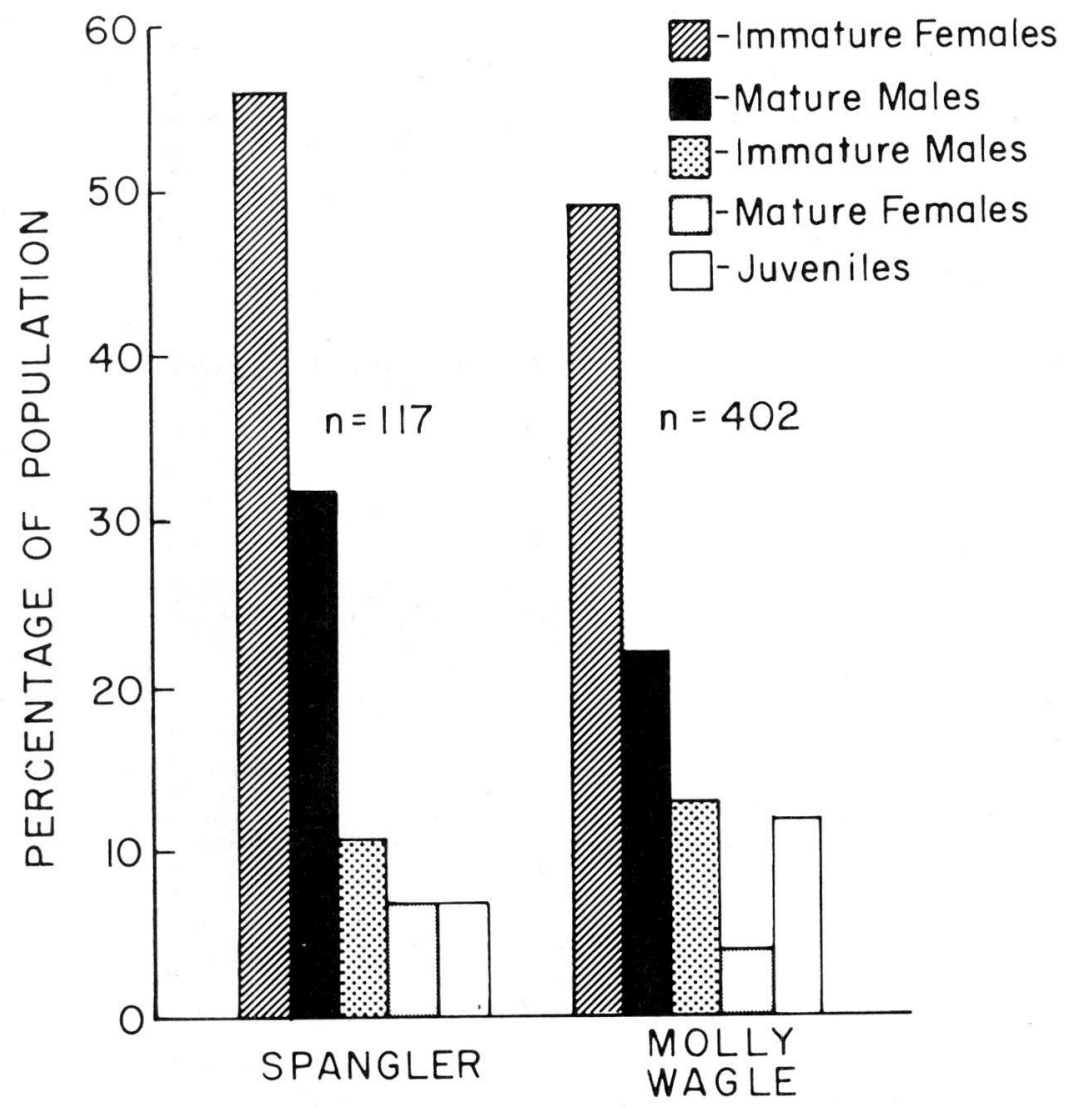

Fig. 5. Long term $C$. antennatus population structures from Molly Wagle and Spangler caves. Population class percentages based on the total number of individuals collected in periodic sampling from 1965 to 1975 . Population structure of individual collections almost always reflected these overall features. 
the egg productivity in $C$. antennatus. As further evidence, no ovigerous females were observed during the entire year in Gallohan No. 2 Cave, the most foodpoor habitat studied. Circannian reproductive patterns have been reported in other troglobitic crustaceans, including crayfish (Jegla, 1966; Jegla and Poulson, 1971; Hobbs, 1973, 1976; Cooper, 1975, 1978), shrimp (Barr and Kuehne, 1971; Cooper, 1975; Cooper and Cooper, 1974), amphipods (Ginet, 1960, 1969; Gledhill and Ladle, 1969), isopods (Magniez, 1975, 1976; Henry, 1976), and copepods (Husson, 1971).

Ovigerous females carried more eggs per clutch in pool-dwelling populations than in stream-dwelling populations. Based on the linear relationship between body length and egg number, clutch size appears to be influenced by larger females associated with the pool habitat (Dickson, 1977a). Increase in egg number correlated with increasing female body length has been observed in other amphipods (Kinne, 1961; Cooper, 1965; Gledhill and Ladle, 1969; Strong, 1972), although this relationship is not always linear (Sprules, 1967).

In $C$. antennatus (pool and stream populations lumped), the mean clutch size is 36 and the number of eggs per mm of female body length is 3.8. In a study of the epigean amphipod Crangonyx richmondensis laurentianus from a lake in Ontario, Canada, Sprules (1967) determined the mean clutch size of this population to be 43 , and based on the data given in his paper, the number of eggs per $\mathrm{mm}$ of female body length would be 3.12. Sprules also found the mean egg diameter to be 0.54 . Both the clutch size and number of eggs per mm of body length in this epigean species is a little larger than those values calculated for $C$. antennatus, although the mean egg size is slightly lower. However, in comparison with troglobitic amphipods of the genus Stygobromus, the mean clutch size and number of eggs per $\mathrm{mm}$ of body length in C. antennatus are relatively large. For example in Stygobromus mackini from caves in southwestern Virginia and northeastern Tennessee, the mean clutch size is 6.43 and the number of eggs per $\mathrm{mm}$ of female body length is 0.95 ; in S. spinatus from caves in southern West Virginia, the mean clutch size is 5.15 and the number of eggs per mm of body length is 0.96 (see Holsinger, 1978). The larger number of eggs per unit of body length in $C$. antennatus, which is closely similar to that of at least one population of epigean congener, may indicate a lower level of adaptation of this species to the subterranean environment than is present in species of Stygobromus. This tends to support the findings of Holsinger (1969) and Culver (1976) who concluded that C. antennatus was less specialized as a troglobite than species of Stygobromus.

The distinct pattern in the number of juveniles in pool habitats may be due to two processes. Although no direct observations were made, evidence of adult cannibalism of juveniles occurred in laboratory cultures (Holsinger and Dickson, 1977). Cannibalism also may be occurring in the densely populated pool populations (Dickson, in press) as was reported in populations of Niphargus (Ginet, 1960). Another possible explanation is the general avoidance activity of juvenile $C$. antennatus in relation to adults. In laboratory cultures, extreme avoidance reactions of juveniles have been observed in confrontations with adults, along with an increase in juvenile burrowing and congregation in crevices and other areas which exclude adults. Both of these 
processes, cannibalism and avoidance, may be occurring in the densely populated pool habitats, causing the low number of juveniles.

Data from laboratory cultures suggest that life span of $C$. antennatus may extend from 8 to 10 years. This life span far exceeds that of epigean amphipods, which generally live one to two years (Pennak, 1953; Hynes, 1954; Sprules, 1967). Increased longevity has been observed in other troglobitic crustaceans. Ginet (1960) reported that the amphipod Niphargus orcinus virei may have a life span of six years. Several subspecies of the isopod Stenasellus virei have been estimated to live 12 to 15 years (Magniez, 1975). Data from a long term, in situ, study suggest the possibility that the troglobitic crayfish Orconectes australis australis may live more than 37 years (Cooper, 1975; Cooper and Cooper, 1976). This increased longevity is considered to be an adaptation associated with population stability in the energy limited cave environment.

Population stability also can be enhanced through the maintenance of specific population structures. Crangonyx antennatus populations display such a modified structure. Populations are characterized by large numbers of immature females and mature males, with a very small percentage of mature females (Fig. 4). There appears to be some form of female recruitment in $C$. antennatus from the immature to the mature stage. An explanation (see Emlen, 1973) may be given for the presence of late female maturity compared to the early maturation of males in this species. Crangonyx antennatus females have been found to produce larger numbers of eggs with increasing body length, thus maximum fecundity occurs in larger (i.e., older) females. Because reproductive activities at one age may diminish the chances of surviving to reproduce at later ages, selection pressure would oppose early reproduction. Survival of female $C$. antennatus through egg bearing periods could be affected by increased energy expenditures associated with egg production, greater susceptibility to predation, and the possibility of additional molting accidents. Overall reproductive success would be expected to be affected more by egg number than sperm number, so selection for late maturity should be stronger in females than males. The low percentage of mature females would also allow a means of controlling population size prior to expenditure of energy in egg formation.

The mechanism of sexual maturation in females is unknown at this time. Reaching a specific size range does not appear to trigger maturation, as many of the immature females are larger than mature females (Dickson and Holsinger, unpublished data).

The population structure of $C$. antennatus was constant both over the year studied and in different aquatic habitats (Fig. 4). In epigean amphipods, population structure changes seasonally, reflecting the growth and maturation of annual or biennial generations (Hynes, 1954; Sprules, 1967). Based on collections from both a pool and a stream, the structure of $C$. antennatus populations was also found to be temporally stable over a 10 -year period.

In $C$. antennatus, the selection of a highly structured population adapted to subterranean conditions apparently outweighs the selective pressures caused by different aquatic habitats. Populations inhabiting lotic and lentic si- 
tuations exhibit quite similar population structures, but they possess morphological and behavioral differences (Dickson, 1977a, 1977b). From these data, it appears that in $C$. antennatus group selected characteristics (population structure) are less variable than individually selected traits (morphology, rheotactic behavior). Emlen (1973) states that under food limited situations group selection becomes an important process. Reproductive patterns were not found to differ in the troglobitic crayfish, Orconectes inermis inermis living under different conditions of food availability (Jegla et al., 1965). In contrast, the epigean amphipod Hyalella azteca exhibited shifts in population structure associated with habitat differences (Strong, 1972). The one exception to the generalized population structure in $C$. antennatus was found in Roadside No. 1 Cave, but the characteristics of this population may be due in part to the presence of an unusually rich food source (raccoon dung).

With respect to egg productivity (i.e., the number of eggs per $\mathrm{mm}$ of $\mathrm{fe}$ male body length), $C$. antennatus is more similar to at least one epigean congener than it is to troglobitic species of Stygobromus. But aside from this, $C$. antennatus has apparently evolved the other K-selected characteristics normally associated with troglobite specialization. In a recent study by Franz (1978) on the troglobitic crayfish Procambarus (Ortmannicus) lucifugus and $P$. (Ortmannicus) erythrops living in food-rich cave systems in Florida, the number of eggs produced by these species was found to be potentially as large as that of a closely related epigean species living in the same general area. Based on our observations of $C$. antennatus and those of Franz (1978) on crayfish, it appears that variation in egg productivity in less specialized troglobites may be influenced by environmental factors such as the availability of food. However, a decrease in egg number as one of the final steps in adaptation to a cave-dwelling existence should be viewed with some caution.

\section{ACKNOWLEDGMENTS}

For assistance with the field work we wish to thank George D. Corbett, David C. Culver, Jeanne Dickson, James A. Estes, Carol J. Haley, Stephen W. Hetrick, and David Wapinski. We are grateful to Mrs. Eleanor Berry, owner of Molly Wagle Cave, and to other cave owners in Lee Co., Virginia, for their cooperation in allowing us access to their property.

\section{ZUSAMMENFASSUNG}

Populationen des unterirdischen Amphipod Crangonyx antennatus in Höhlen im Lee Co., Virginia (U.S.A.) wurdenauf einer kurzfristigen un einer langfristigen Basis untersucht. Die Dynamik von Populationen die in zwei verschiedenen Höhlenfundorten (schlammgrundige Teiche und steingrundige Flüsse) leben wurden jahreszeitsweise für ein Jahr verglichen. Das Verhältnis von Mannchen zu Weibchen deutete eine grössere Anzahl von Weibchen im Teich sowohl als auch im Fluss an. Die Mehrzahl der Männchen an beiden Fundorten waren während der ganzen Jahreszeit uber geshclechtsfähig. Jahreszeitliche Schwankungen in der Geschlechtsreife der Weibchen konnte an beiden Fundorten beobachtet werden, wobei die Anzahl der gesammelten Weibchen im Juni und August grösser war. Ausserdem wurde eine grössere Anzahl von eierlegenden Weibchen im Frühjahr beobachtet, was die Möglichkeit eines circannischen Fortpflanzungszykluses im Teich und Fluss andeutet. Die Struktur der untersuchten Populationen in Höhlen scheint die kontrollierte Umwandlung von geschlechtlich unreifen zu geschlechtlich reifen Weibchen zu reflektieren. 
Um die stabilität der Populationenstruktur zu bestimmen, wurden Werte von einer 10 jährigen Zeitspanne eines Teich- und Flussfundortes analyziert. Die Populationenstruktur zeigten eine relative Stabilität, uber lange Zeitspannen an beiden Fundorten, wobei die geschlechtlich unreifen Weibchen die herrschende Populationenklasse bildeten.

\section{LITERATURE}

BARR, T.C., Jr., and R.A. KUEHNE 1971. Ecological studies in the Mammoth Cave system of Kentucky. II. The ecosystem. Annales de Spéléol. 26:2-96.

COOPER, J.E. 1975. Ecological and behavioral studies in Shelta Cave, Alabama, with emphasis on decapod crustaceans. Unpublished doctoral dissertation, University of Kentucky.

COOPER, J.E., and M.R. COOPER 1974. Distribution and ecology of troglobitic shrimp of the genus Palaemonias (Decapoda: Atyidae). Assoc. Southeastern Biol. Bull. 21:48 (abstr.).

COOPER, J.E., and M.R. COOPER 1978. Comparative reproductive strategies of troglobitic crayfishes in Shelta Cave, Alabama. Assoc. Southeastern Biol. Bull. 25:44 (abstr.).

COOPER, M.R., and J.E. COOPER 1976. Growth and longevity in cave crayfishes. Assoc. Southeastern Biol. Bull. 23:52 (abstr.).

COOPER, W.E., 1965. Dynamics and production of a natural population of a freshwater amphipod, Hyalella azteca. Ecol. Monogr. 35:377-394.

CULVER, D.C. 1976. The evolution of aquatic cave communities. Am. Nat. 110:945-957.

CULVER, D.C., and J.R. HOLSINGER 1969. Preliminary observations on sex ratios in the subterranean amphipod genus Stygonectes (Gammaridae). Am. Midl. Nat. 82:631-633.

DICKSON, G.W. 1977a. Variation among populations of the troglobitic amphipod crustacean Crangonyx antennatus Packard living in different habitats. I. Morphology. Int. J. Spéléol. 9:43-58.

DICKSON, G.W. 1977b. Behavioral adaptation of the troglobitic amphipod crustacean Crangonyx antennatus to stream habitats. Hydrobiologia 56:17-20.

DICKSON, G.W. 1979. The importance of cave mud sediments in food preference, growth and mortality of the troglobitic amphipod crustacean Crangonyx antennatus Packard (Crangonyctidae). Crustaceana 36:129-140.

DICKSON, G.W. In press. Variation among populations of the troglobitic amphipod crustacean Crangonyx antennatus Packard (Crangonyctidae) living in different habitats. II. Population distribution. Int. J. Spéléol.

DICKSON, G.W. and P.W. KIRK, Jr. 1976. Distribution of heterotrophic microorganisms in relation to detritivores in Virginia caves. (With supplementary bibliography on cave mycology and microbiology), in: The distributional history of the biota of the southern Appalachians. Part IV. Algae and fungi, PARKER B.C. and ROANE M.K., Eds., University Press of Virginia, Charlottesville: 205-226.

EMLEN, J.M. 1973. Ecology: An evolutionary approach. Addison-Wesley, California.

FRANZ, R. 1978. Ecological strategies of closely-related surface and troglobitic Florida crayfishes. Bull. Ecol. Soc. Am. 59:70 (abstr.).

GINET, R. 1960. Écologie, éthologie et biologie de Niphargus (Amphipodes, Gammarides hypogés). Annales de Spéléol. 15:127-376.

GINET, R. 1969. Rythme saisonnier des reproductions de Niphargus (Crust. Amph. hypoge). Annales de Spéléol. 24:387-397.

GLEDHILL, T. and M. LADLE 1969. Observations on the life-history of the subterranean amphipod Niphargus aquilex aquilex Schiodte. Crustaceana 16:51-56.

HENRY, J.P. 1976. Recherces sur les Asellidae hypogés de la lignés cavaticus (Crustacea, Isopoda, Asellota). Unpublished doctoral thesis, Université de Dijon, France.

HEUTS, M.J. 1951. Ecology, variation and adaptation of the blind African cave fish, Caecobarbus geertsi. Annales Soc. Roy. Zool. Belgium 82:155-230.

HOBBS III, H.H. 1973. The population dynamics of cave cray fishes and their commensal ostracods from southern Indiana. Unpublished doctoral dissertation, Indiana University.

HOBBS III, H.H. 1976. Molt cycle, size and growth in Orconectes inermis inermis Cope (Decopoda: Cambaridae). Va. J. Sci. 27:44 (abstr.).

HOLSINGER, J.R. 1969. Biogeography of the freshwater amphipod crustaceans (Gammaridae) 
of the central and southern Appalachians, in: The distributional history of the biota of the southern Appalachians. Part I. Invertebrates, HOLT P.C., Ed., Virginia Polytechnic Institute Press, Blacksburg, Va.: 19-50.

HOLSINGER, J.R. 1972. The freshwater amphipod crustaceans (Gammaridae) of North America. Biota of Freshwater Ecosystems, Identification Manual 5, U.S. Environmental Protection Agency.

HOLSINGER, J.R. 1978. Systematics of the subterranean amphipod genus Stygobromus (Crangonyctidae), Part II: Species of the eastern United States. Smithsonian Contributions to Zoology No. 266:1-144.

HOLSINGER, J.R. and C.H. HOLSINGER 1971. Observations on the population ecology of the cavernicolous amphipod crustacean Crangonyx antennatus Packard. Va. J. Sci. 22:97 (abstr.).

HOLSINGER, J.R. and G.W. DICKSON 1977. Burrowing as a means of survival in the troglobitic amphipod crustacean Crangonyx antennatus Packard (Crangonyctidae). Hydrobiologia 54:195-199.

HUSSON, R. 1971. Rythmes biologiques et vie cavernicole. Bull. Soc. Zool. France 96:301-316.

HYNES, H.B.N. 1954. The ecology of Gammarus dueboni Lilljeborg and its occurrence in fresh water in western Britain. J. Anim. Ecol. 23:38-84.

JEGLA, T.C. 1966. Reproductive and molting cycles in cave crayfish. Biol. Bull. 130:345-358.

JEGLA, T.C. and T.L. POULSON 1970. Circannian rhythms-I. Reproduction in the cave crayfish, Orconectes pellucidus inermis. Comp. Biochem. Physiol. 33:347-355.

JEGLA, T.C., T.L. POULSON and M.R. COOPER 1965. Interpopulation variations in a cave crayfish (Orconectes pellucidus). Am. Zool. 5:639 (abstr.).

KINNE, O. 1961. Growth, molting frequency, heart beat, number of eggs, and incubation time in Gammarus zaddachi exposed to different evironments. Crustaceana 2:26-36.

MACARTHUR, R.H. and E.O. WILSON 1967. The theory of island biogeography. Princeton University Press, New Jersey.

MAGNIEZ, G. 1975. Observations sur la biologie de Stenasellus virei. Int. J. Spéléol. 7:79-228.

MAGNIEZ, G. 1976. Remarques sur la biologie et l'ecologie de Stenasellus virei Dollfus (Crustacea, Isopoda Asellota des eaux souterraines) Int. J. Spéléol. 8:135-140.

PENNAK, R.W. 1953. Freshwater invertebrates of the United States. Ronald Press, New York. POULSON, T.L. 1963. Cave adaptation in Amblyopsid fishes. Am. Midl. Nat. 70:257-290.

SPRULES, W.G. 1967. The life cycle of Crangonyx richmondensis laurentianus Bousfield (Crustacea: Amphipoda). Can. J. Zool. 45:877-884.

STRONG, D.R. 1972. Life history variation among populations of an amphipod (Hyalella azteca). Ecology 53:1103-1111.

TURNER, R.D. and W.J. CLENCH 1974. A new blind Physa from Wyoming with notes on its adaptation to the cave environment. Nautilus: 88:80-85.

VANDEL, A. 1965. Biospeleology. The biology of cavernicolous animals. Pergamon Press, New York. 